\title{
Rapid PCR Based Detection of Buffalo Milk in Cow Milk
}

\author{
A.S. Khade*, B.K. Maurya, S.K.J. Ebenezer, S.M. Patel, \\ A. Balakrishnan and Rajesh R. Nair \\ National Dairy Development Board, Anand, Gujarat, India \\ *Corresponding author
}

\section{A B S T R A C T}

Keywords

Cattle, Buffalo, Milk, Adulteration, PCR

Article Info

Accepted:

07 March 2019

Available Online:

10 April 2019

\begin{abstract}
The study was undertaken with an objective to evaluate a rapid PCR based method for detection of adulteration of buffalo milk in cow milk at minimum level of detection. This method utilizes primers targeting the mitochondrial encoded 12S rRNA gene as the target for species identification. PCR assay involve use of three different primers. Reverse primers specific for cow and buffalo complementary to the gene fragment of $12 \mathrm{~S}$ rRNA along with the common forward primer. The cow specific primer, along with the common forward primer, yields a cow specific amplicon of $346 \mathrm{bp}$ in the $12 \mathrm{~S}$ rRNA gene. On the other hand, a buffalo specific primer along with the same common forward primer yields a buffalo specific amplicon of $220 \mathrm{bp}$ fragment in the same gene. The method evaluated was able to detect presence of buffalo milk in cow at $0.5 \%$ level of adulteration.
\end{abstract}

\section{Introduction}

In recent times, with increasing consumption of dairy food items, the species identification of milk and milk products has received a great attention. It has a significant importance for several reasons related to government regulations, religion and public health. The extensive consumption of milk and dairy products makes these foodstuffs targets for potential adulteration with financial gains for unscrupulous producers (Nicolaou et al., 2011). In the dairy sector, the fraudulent misdescription of food contents on product labels has been reported especially with high added value milk products commanding a premium price. The description and labeling of food must be accurate so that consumers can make informed choices about their diet and the products they buy (Herman, 2001; Herna'ndez et al., 2003)

Testing authenticity of food products such as milk, meat and fish is important for labeling and assessment of value and is therefore important to prevent unfair competition and assure consumers protection against fraudulent practices commonly observed in the food industry (Xue et al., 2010). The majority of dairy products' authenticity testing methodologies are based on major milk proteins analysis (Stanciuc and Rapeanu, 
2010). Different analytical approaches have been used for milk species identification such as immunological (Xue et al., 2010; Zelenakova et al., 2008; Hurley et al., 2004), electrophoretical (Mayer, 2005) and chromatographic (Enne et al., 2005).

With recent advances in DNA technology, DNA based methods are been used for many aspects of food authentication, including milk adulteration detection (Woolfe and Primrose, 2004).Molecular techniques have proved to be reliable, sensitive and fast. Among molecular techniques, PCR is the most widely used test for the identification of species of origin in milk (Bottero et al., 2003).Recent studies have shown that it is possible to use milk as a source of DNA and as a substrate for PCR. Ruminant milk from healthy mammary glands has a large amount of somatic cells which contain genomic DNA suitable for PCR amplification (Amills et al., 1997; Lipkin et al., 1993; Murphy, Reza et al., 2002). Accurate species identification by PCR is highly dependent on the specificity of primers used. These primers should target a DNA fragment with sufficient species to species variation.

The objective of the study was to evaluate PCR technique for its sensitivity and applicability for detection of buffalo milk in cow milk at lowest possible limit of adulteration.

\section{Materials and Methods}

\section{Sample collection}

Experimental material for present study comprised of Milk Samples. Twenty different batches of pure raw milk of both cow and buffalo were collected as standard milk samples from local dairy farms. Milk samples were transported to the laboratory under cold chain and processed immediately. The pure buffalo milk samples were mixed in pure cow milk at different levels making final volume of $20 \mathrm{ml}$ (Table 1).

\section{Extraction of DNA from Milk}

DNA was extracted from the milk samples using protocol for the isolation of the genomic DNA from the cattle and buffalo milk using Universal DNA Extraction Kit (DSS-DNEU011).The quantity and quality of DNA was checked by spectrophotometer (Biospec Nano) and agarose gel electrophoresis respectively.

\section{Polymerase Chain Reaction}

We used 3 different primers targeting the mitochondrial 12S rRNA gene as the target for species identification. The primers were synthesized from Invitrogen (USA) according to sequences reported by Lopez Calleja et al., 2004. The primers included common forward (F-5' CTA GAG GAG CCT GTT CTA TAA TCG ATA A 3') and species specific reverse (5' AAA TAG GGT TAG ATG CAC TGA ATC CAT 3') and (5' TTC ATA ATA ACT TTC GTG TTG GGT GT 3') respectively for cow and buffalo. Various combinations of primers and DNA of cattle and buffalo origin were tested in a final volume of $25 \mu \mathrm{l}$ containing $2 \mathrm{x}$ PCR master mix (Thermo scientific, USA) 10 pmole of each primer and 60-90 ng of DNA template (cattle and/or buffalo). Amplification was performed in Master Cycler gradient thermocycler (Applied Biosystems Veriti, USA) with the following cycling conditions: after an initial denaturation at $93^{\circ} \mathrm{C}$ for 3 minutes, 40 cycles were programmed as follows: $93^{\circ} \mathrm{C}$ for 30 seconds, $63^{\circ} \mathrm{C}$ for 30 seconds, $72^{\circ} \mathrm{C}$ for 120 seconds and final extension at $72^{\circ} \mathrm{C}$ for 10 minutes. The amplified PCR products obtained from experimental mixtures were subjected to agarose gel electrophoresis and visualized under UV to check amplification of 
the fragment. The optimized PCR amplified a $346 \mathrm{bp}$ product for cattle and a $220 \mathrm{bp}$ product for buffalo which were confirmed by using Gel documentation system (G-box, Syngene, UK).

\section{Results and Discussion}

The present study was carried out to check efficacy of PCR method to detect minimum level of adulteration of buffalo milk in cow milk. The DNA samples with an OD ratio of 1.8 to $2.0\left(\mathrm{OD}_{260: 280}\right)$, appeared as a single compact fluorescent band free from shearing and contamination on agarose gel electrophoresis were subjected to PCR. For the PCR amplification, a suitable annealing temperature was tested from a range of 55$65^{\circ} \mathrm{C}$ in the mastercycler gradient. Consistent results were obtained at $63^{\circ} \mathrm{C}$. To evaluate the specificity of the primers, PCR amplification of cow's milk DNA with cow specific primer pair and of buffalo milk DNA with buffalo specific primer pair was performed. The expected PCR fragment of $346 \mathrm{bp}$ was amplified in all batches of pure cow milk, whereas no amplification products were observed with DNA extracted from buffalo milk (Fig. 1). Similarly, expected buffalo specific amplicon of $220 \mathrm{bp}$ was amplified in all batches of pure buffalo milk, whereas no amplification products were observed with DNA extracted from cow milk (Fig. 2).

Table.1 Pure buffalo milk mixed in pure cow milk at different levels

\begin{tabular}{|c|c|c|c|c|c|}
\hline $\begin{array}{c}\text { Sr. } \\
\text { No. }\end{array}$ & $\begin{array}{c}\text { Cow Milk } \\
(\mathbf{m l})\end{array}$ & $\begin{array}{c}\text { Buffalo } \\
\text { Milk (ml) }\end{array}$ & $\begin{array}{c}\text { Total Mix } \\
(\mathbf{m l})\end{array}$ & Mix \% & Remark \\
\hline $\mathbf{1}$ & 19.9 & 0.1 & 20 & $0.5 \%$ & Buffalo milk mixed in Cow milk \\
\hline $\mathbf{2}$ & 19.8 & 0.2 & 20 & $1.0 \%$ & \\
\hline $\mathbf{3}$ & 18 & 2 & 20 & $10.0 \%$ & \\
\hline $\mathbf{4}$ & 14 & 6 & 20 & $30.0 \%$ & \\
\hline $\mathbf{5}$ & 10 & 10 & 20 & $50.0 \%$ & Pure Cow milk \\
\hline $\mathbf{6}$ & 10 & - & 10 & $100.0 \%$ & Pure Buffalo milk \\
\hline $\mathbf{7}$ & - & 10 & 10 & $100.0 \%$ & \\
\hline
\end{tabular}

Fig.1 346bp PCR products of cow-specific 12S rRNA gene amplified using cow specific primers. Lanes 1-5: Cow milk DNA, lane 6: Buffalo milk DNA, lane 7: Negative control, lane M1: 20 bp DNA Ladder, Lane M2: 100bp DNA ladder

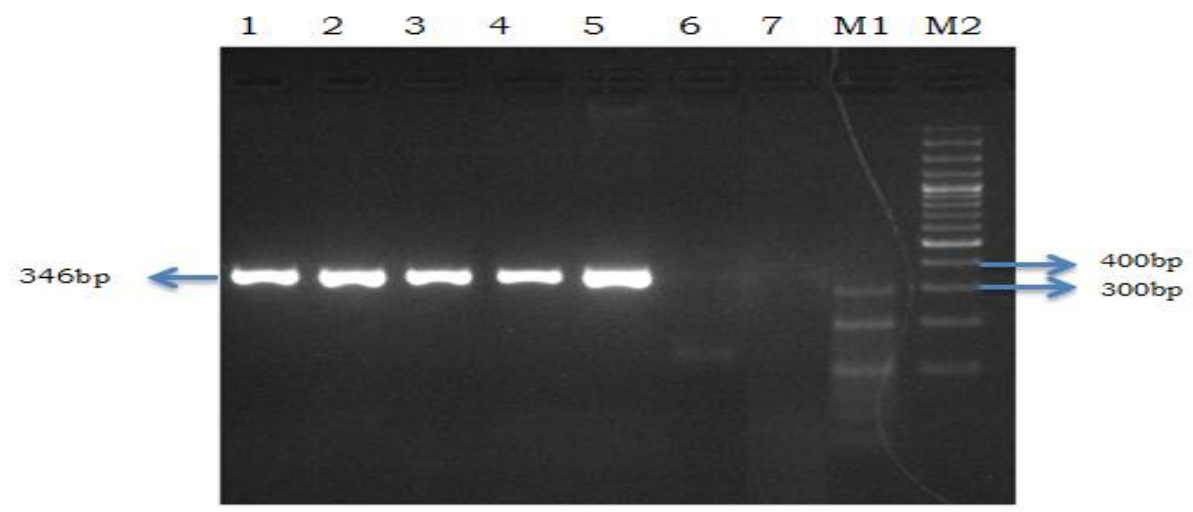


Fig.2 220 bp PCR products of Buffalo specific 12S rRNA gene amplified using buffalo specific primers. Lanes 1-5: Buffalo milk DNA, lane 6: Cow milk DNA, lane 7: Negative control, lane M1: 20 bp DNA Ladder, Lane M2: 100bp DNA ladder

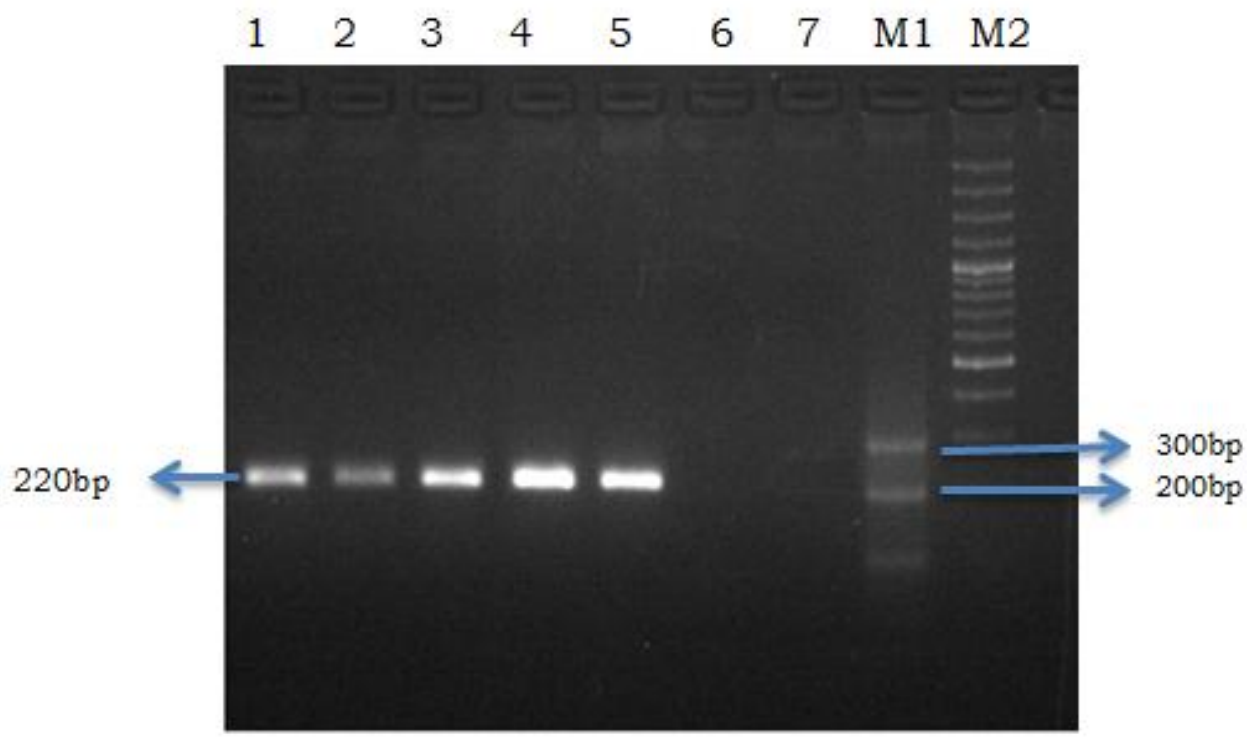

Fig.3 220bp PCR product of buffalo-specific 12S rRNA gene obtained from raw milk mixtures of buffalo in cow milk. Lane 1: 1\% Buffalo milk, Lane 2: 10\% Buffalo milk, Lane 3: 30\% Buffalo milk, Lane 4 \& 7: 100\% Buffalo milk, Lane 5 \& 6: 100\% Cow milk, Lane 8: 50\% Buffalo DNA, Lane 9: Negative Control, Lane 10: 0.5\% Buffalo milk, Lane M1: 20bp DNA Ladder, Lane M2:100bp DNA Ladder

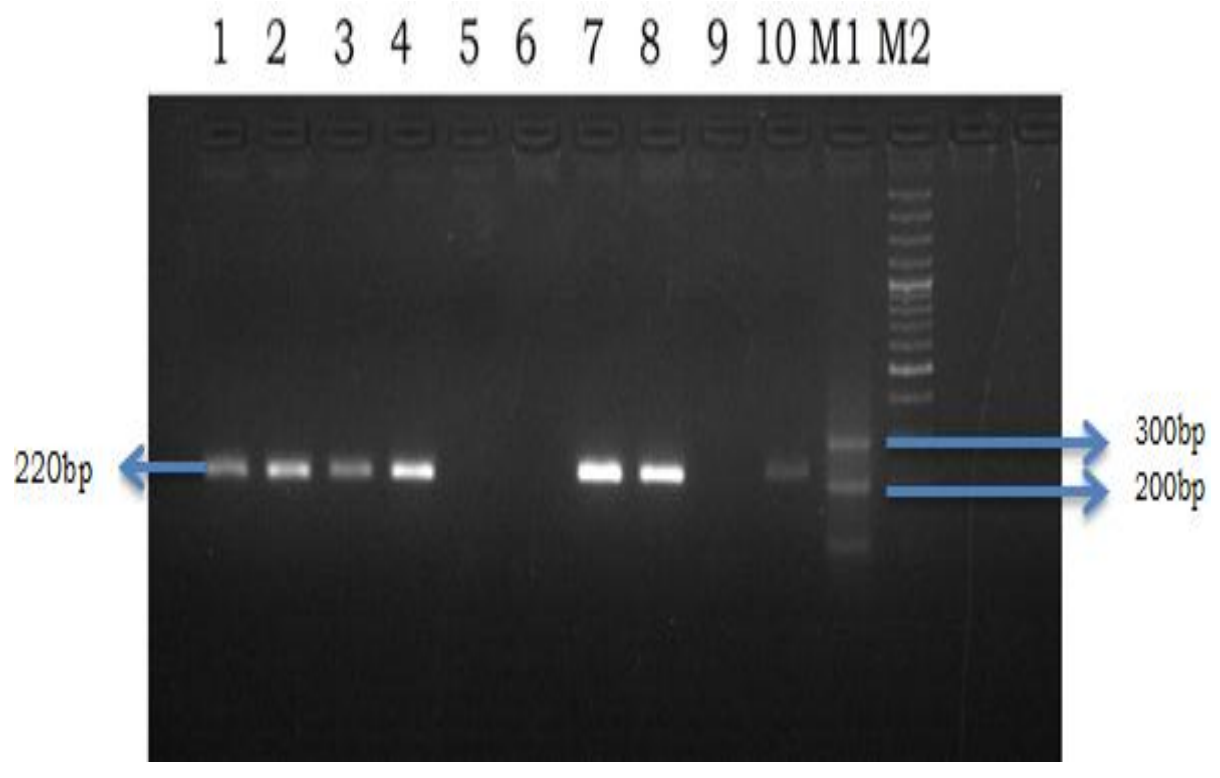


Fig.4 346bp PCR product of cow-specific 12S rRNA gene obtained from raw milk mixtures of buffalo milk in cow milk. Lane 1: $99 \%$ cow milk, Lane: $290 \%$ cow milk, Lane 3: 70\% cow milk, Lane 4 \& 7: 100\% buffalo milk, Lane 5 \& 6: 100\% cow milk, Lane 8: $50 \%$ cow milk, Lane 9: Negative Control, Lane 10: 99.5\% cow milk, Lane M1: 20bp DNA Ladder, Lane M2:100bp DNA Ladder

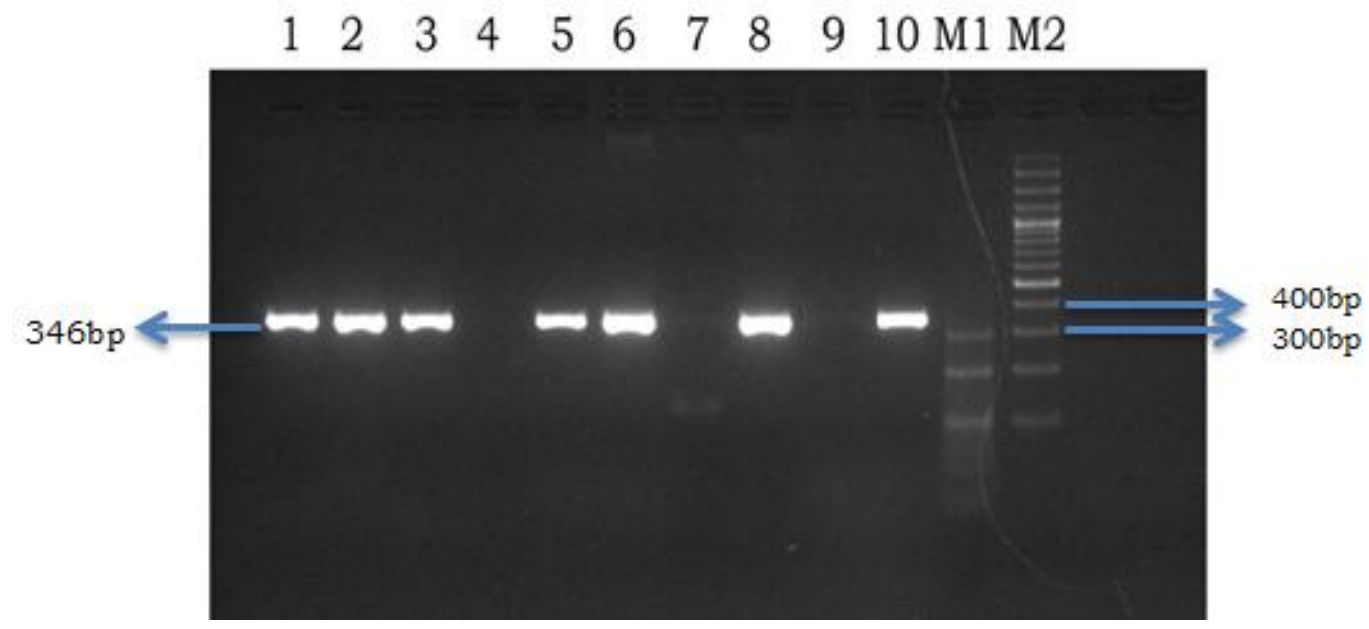

After assessing the specificity of primers used, PCR amplification was performed on binary milk mixtures to determine the sensitivity of the PCR assay. Two separate amplification reactions were performed on DNA extracted from cow/water buffalo raw milk mixtures containing defined percentages of buffalo milk ranging from 0.5 to $100 \%$ (v/v). Figure 3 shows first amplification reaction products obtained using buffalo specific reverse and common forward primer while Figure 4 shows second amplification reaction products obtained using cow specific reverse and common forward primer.

The identification of the species of origin in milk and other milk based products is not only important for the detection of fraudulent manipulations, but also for prevention of food-borne allergic reactions derived from milk proteins (Calvo et al., 2002). Only a few PCR-based protocols have been reported for dairy product authentication till date. With advancement of molecular tools, PCR based molecular methods are being increasingly demanded by food regulatory agencies for the detecting animal food ingredients and their origins (Meyer \&Candrian, 1996). Using appropriate species specific primer pairs, mitochondrial sequences are now been amplified in various species and the resulting differences are been used for species identification (Herman, 2001). In addition, designing specific primers and standardizing adequate protocols for extraction of inhibitor free DNA are still necessary for consistent PCR amplification of a specific target DNA sequence (Tartaglia et al., 1998).

From present study, it can be concluded that cow and buffalo milk could be reliably identified and differentiated using duplex PCR at optimized conditions. The method could detect up to $0.5 \%$ adulteration of buffalo milk in cow milk mixture.

\section{Acknowledgements}

Financial assistance and necessary facilities provided by the management of National Dairy Development Board, Anand, for undertaking this study at Centre for Analysis 
and Learning in Livestock and Food (CALF), are gratefully acknowledged.

\section{References}

Amills, M., O. Francino, M. Jansa and Sa'nchez, A. 1997. Isolation of genomic DNA from milk samples by using chelex resin. Journal of Dairy Research, 64, 231-238.

Bottero, M. T., T. Civera, A. Anastasio, R.M. Turi, and Rosati, S. 2002. Identification of cow's milk in "buffalo" cheese by duplex polymerase chain reaction. Journal of Food Protection, 65, 362366.

Bottero, M. T., T. Civera, D. Nucera, S. Rosati, P. Sacchi and Turi, R. M. 2003. A multiplex polymerase chain reaction for the identification of cow's, goat's and sheep's milk in dairy products. International Dairy Journal, 13, 277282.

Calvo, J. H., R. Osta and Zaragoza, P. 2002. Species-specific amplification for detection of bovine, ovine and caprine cheese. Milchwissenschaft, 57, 444446.

Enne, G., D. Elez, F. Fondrini, I.Bonizzi, M. Feligini and Aleandri, R. 2005. Highperformance liquid chromatography of governing liquid to detect illegal bovine milk addition in water buffalo Mozzarella: Comparison with results from raw milk and cheese matrix. J. Chromatogr. A 1094 (1-2), 169-178.

Herman, L. 2001. Determination of the animal origin of raw food by speciesspecific PCR. Journal of Dairy Research, 68, 420-436.

Herna'ndez, M., A. Ferrando, T. Esteve, P.Puigdome`nech, S. Prat and Pla, M. 2003. Real-time and conventional polymerase chain reaction systems based on the metallo-carboxypeptidase inhibitor gene for specific detection and quantification of potato and tomato in processed food. Journal of Food Protection, 66, 1063-1070.

Hurley, I.P., R.C. Coleman, H.E. Ireland and Williams, J.H.H. 2004. Measurement of bovine IgG by indirect competitive ELISA as a means of detecting milk adulteration. J. Dairy Science, 87, 215221.

Lipkin, E., A, Shalom, H. Khatib, M. Soller and Friedmann, A. 1993. Milk as a source of deoxyribonucleic acid and as a substrate for the polymerase chain reaction. Journal of Dairy Science, 76, 2025-2032.

Lo'pez-Calleja, I., I. Gonza' lez, V. Fajardo, M.A. Rodri'guez, P.E. Herna' ndez, T. Garc1'a and Martı'n, R. 2004. Rapid detection of cow's milk in sheep's and goat's milk by a species-specific PCR technique. Journal of Dairy Science, 87, 2839-2845.

Mayer, H.K. 2005.Milk species identification in cheese varieties using electrophoretic, chromatographic and PCR techniques. Int. Dairy J. 15, 595604.

Meyer, R., and Candrian, U. 1996. PCRbased DNA analysis for the identification and characterization of food components. LebensmittelWissenhauf und-Technologie, 29, 1-9.

Murphy, A. M., M. Reza Shariflou and Moran, C. 2002. High quality genomic DNA extraction from large milk samples. Journal of Dairy Research, 69, 645-649.

Rea, S., K. Chikuni, N. Branciari Nicolaou, Y. Xu and Goodacre, R. 2011. MALDIMS and multivariate analysis for the detection and quantification of different milk species. Anal Bioanal Chem 399, 3491-3502.

Rea, S., K. Chikuni, R. Branciari, R. Sukasi Sangamayya, D. Ranucci and Avellini, P. 2001. Use of duplex polymerase 
chain reaction (duplex PCR) technique to identify bovine and water buffalo milk used in making mozzarella cheese. Journal of Dairy Research, 68, 689-698.

Darwish, S.F., H. A. Allam, and Amin, A.S.2009."Evaluation of PCR assay for detection of cow's milk in water buffalo's milk." World Applied

Sciences Journal 7, no. 4: 461-467.

Stanciuc, N. and Rapeanu, G. 2010. Identification of adulterated sheep and goat cheeses marketed in Romania by immunocromatographic assay. Food and Agricultural Immunology 21 (2), 157-164.

Tartaglia, M., E. Saulle, S. Pestalozza, L. Morelli, G. Antonucci and Battaglia, P. A. 1998. Detection of bovine mitochondrial DNA in ruminant feeds: a molecular approach to test for the presence of bovine-derived materials. Journal of Food Protection, 61, 513518.

Woolfe M. and Primrose, S. 2004. Food forensics: using DNA technology to combat misdescription and fraud. Trends in Biotechnology, 22: 222-226.

Xue, H., W. Hu, H. Son, Y. Han and Yang, Z. 2010.Indirect ELISA for detection and quantification of bovine milk in goat milk. J. Food Sci. Tech. 31 (24), 370373.

Zeleňáková, L. and Golian, J. 2008. Application of ELISA tests for detection of milk and cheese adulteration, Sci. Monograph. SPU Nitra, 98.

\section{How to cite this article:}

Khade, A.S., B.K. Maurya, S.K.J. Ebenezer, S.M. Patel, A. Balakrishnan and Rajesh R. Nair. 2019. Rapid PCR Based Detection of Buffalo Milk in Cow Milk. Int.J.Curr.Microbiol.App.Sci. 8(04): 791-797. doi: https://doi.org/10.20546/ijcmas.2019.804.087 